\title{
Political Economy From the Perspective of Ibn Khaldun
}

\author{
Moch. Bukhari Muslim ${ }^{1}$, Saepullah $^{2}$, Any Widayatsari ${ }^{3}$
}

\begin{abstract}
The political economy encompasses the management of revenues and spending to achieve the social welfare of the community. Hence, development is not solely emphasized economic growth but also equity. This article discusses the political economy according to Ibn Khaldun, written in his book, Muqaddimah. This study concludes that that political budgets must be carried out in a balanced manner by establishing budget certainty and increasing the discipline in use of the budget. Legislators make laws, referring to the creation of income sources so that the community will be able to meet their needs independently, and the government can gather capabilities to carry out their duties and functions. Ibn Khaldun saw budget management as a means to solve public matters while also factoring the interests of rulers and governments.
\end{abstract}

Keywords: Budget, Government, Income, Management, Spending

\begin{abstract}
Abstrak. Ekonomi politik meliputi pengelolaan pendapatan dan pengeluaran untuk mencapai kesejahteraan sosial masyarakat. Karenanya, pembangunan adalah tidak semata-mata menekankan pertumbuhan ekonomi tetapi juga pemerataan. Artikel ini membahas tentang ekonomi politik menurut Ibnu Khaldun, ditulis dalam bukunya, Muqaddimah. Studi ini menyimpulkan bahwa anggaran politik harus dilakukan secara seimbang cara dengan menetapkan anggaran kepastian dan meningkatkan disiplin dalam penggunaan anggaran. Legislator membuat undang-undang, merujuk pada penciptaan sumber pendapatan sehingga masyarakat akan dapat memenuhi kebutuhan mereka secara mandiri, dan pemerintah dapat mengumpulkan kemampuan untuk melaksanakan tugas dan fungsinya. Ibn Khaldun melihat manajemen anggaran sebagai sarana untuk menyelesaikan masalah publik sementara juga anjak kepentingan para penguasa dan pemerintah.
\end{abstract}

Kata kunci: Anggaran, Pemerintah, Pendapatan, Manajemen, Pengeluaran 


\section{Introduction}

State income and expenditure budget is the main defining factor in economic stability and social welfare. Management of state income and expenditure budget is a part of political economy in order to improve the social economy. Syarifuddin, quoting Aaron Wildavsky, explains that all budgeting is subject to politics because budgeting is part of the political game (George C. Abbott 1985, 111; Tony Smith $1985,122-124)$. Herzon adds that the process and product of budgeting is a political product, and does not exclude the possibility of manipulation, domination, cuts, closed decision making and other harmful practices related to budgets (Herzon Y. n.d.). Economic development has to create growth that is equal to all members of society

Among issues in the government policy is related to public finance. Fiscal policy plays a key part in managing state income and expenditure. This article discusses the relationship between public finance, fiscal policies and government efforts to create social welfare. Political Economy, according to Martin Staniland (1985), is the study of social issues and retardation (George C. Abbott 1985, 111; Tony Smith 1985, 122-124). Meanwhile, newer political economists define the political economy as the analysis of the economic process (Deliarnov 2006, 8-9). Deliarnov states that the scope of political economy is very large and is interdisciplinary, encompassing economy, politics, social studies and culture (Deliarnov 2006, 10).

\section{State Economy in Budget Management}

Post World War II, countries underwent massive economic depression and finding a solution became a discourse for economists around the globe. John Maynard Keynes (henceforth referred to as Keynes), proposed a solution through fiscal stimuli (Robert Skidelsky and Robert Jacob Alexander Skidelsky 2008, 1-3). Keynes' idea was abandoned in 1970 but started to be used again from 2008 and 2009 (Geoffrey Pilling 1987; Sumita Kale 2008).

Keynes argued that depression and political stagnation could be controlled by giving freedom to countries or government to perform economic supervision. The free market offered by neo-classics in order to overcome depression will not always lead to a stable economy (Robert Skidelsky and Robert Jacob Alexander Skidelsky 2008, 29). Keynes' theory is an antithesis to the free market theory, with their terms of laissez-faire or lets do. Keynes believes that the rise in demand is determined by government policies. The government must be proactive in improving aggregate demand by increasing spending and creating easy-to-obtain money conditions. If the government decreases tax and increases spending, people's spendable income 
increases and consumption will tend to increase (Robert Skidelsky and Robert Jacob Alexander Skidelsky 2008, 33).

Government expenditure and tax policies will affect spending, financial and supply. The government, for example, builds a highway. In this case, spending on highway construction will directly affect the increase in economic activities. If the construction were funded from selling bonds to private companies, then, the wealth in the private sector would increase, and this financial effect will impact the spending. Furthermore, the new highway will improve economic infrastructure, lead to the rise of economic potential and supply (Roslinda 2013).

According to Keynes, inflation is caused by people who want to live outside their economic capabilities. Inflation occurs as an effect of over-demand and causes an inflationary gap (Prathama Raharja and Mandala Manurung 2008, 36). Keynes states that the inflation rate is not solely caused by a monetary factor such as the amount of money in circulation, but also determined by production cost. The government has to be involved in controlling the inflation rate by implementing appropriate fiscal policies. Fiscal policies will be better in solving the inflation problem than monetary policies (Nopirin 1998, 72-75). Expansionary fiscal policies will increase outputs, while monetary expansion with additional money supply will not affect the outputs (Nopirin 1998, 72-75). The government must decrease the expenditure with fiscal policies such as increasing tax rates and enforcing strict financial policies. Keynes' theory is applied to explain short term inflation (Nopirin, 1998, 80-85).

According to Keynes, unemployment plays a key part in macroeconomic issues (Adrian Sutedi 2012, 52-55). Unemployment happens because the level of economic activity achieved is lower than that of an economy with full employment. Unemployment is categorized into two types, voluntary unemployment and involuntary unemployment. Voluntary unemployment happens when someone chooses to not work rather than to work with a low wage, while involuntary unemployment occurs when a worker wants to work at a certain wage but does not manage to find a job opportunity (Jacob Viner 1936, 147-167).

The solution offered by Keynes is that the government manages community demand through management that directs public demand for abundant goods and services. The government must invest a lot to open up more jobs. So the unemployment rate will be decreased (Jacob Viner 1936, 147-167). The economy of a country will experience steady growth if accompanied by an increase in savings. According to Keynes, a person's expenditure for consumption and savings is influenced by the level of income. If a person's income level gets smaller, then all his income will only be enough for consumption purposes, and there is nothing 
left for savings. An increase in spending or consumption will increase production activities and income. An increase in this income will, eventually, encourage the increase in consumption and savings (Michael James 2001, 49; Todaro 2002, 213). Higher savings will be able to increase production, and encourage economic expansion so that economic growth will be achieved. Different from classical school views, Keynes pointed out that the main determinant of consumption and saving accumulation is the rate of income, not interest rates (N. Gregory Mankiw 2006, 245; John Maynard Keynes n.d.).

\section{Fiscal as a Regulator of Income and Expenditure}

The main purpose of a country's economic policy is to create social prosperity and welfare. Therefore the study of political economy is directed towards the public interest. The study of political economy according to conventional groups or neoclassical schools is the strategy of legislators to achieve two objectives: first, creating a source of income or creating self-sufficiency for the people, and second, preparing strength for the government to be able to carry out their duties and functions well (Ng. Philipus and Nurul Aini 2004, 16-19). As for Islamic political economy, the study is implementing theory and practice in harmony or monotheistical epistemology (Faridi 1983, 15-30).

An important part of political economy studies is about public finance. Public finance is a branch of economics that examines procurement, maintenance, and budget expenditures needed by a government to run the duties and function. So, public finance is always related to government finance. The main focus of public finance study is analyzing the impact of taxation and government spending on the state's economy as a whole (A.C. Pigou 1951, 46).

The main topic in the public finance study is regarding fiscal. Fiscal policies are one of the policies related to the state economy. The main theme of fiscal policies is the strategy of managing the flow of state income and expenditure. In Arabic, fiscal policy is synonymous to siyāsah mäliyah or siyäsah darbiyah (Abdullah M. Farid 1985, 104).

Economists define fiscal policies according to their economic views (Frans Seda 2004, 75-76). Capitalist economists, on the other hand, define fiscal policies as an effort to create a condition that determines the success of investment growth and alleviate fluctuations in economic economy as a whole. Another aim is to bridge the gap between inflation and deflation that can define the level of income, influenced by the lack of investment; and to increase the expenditure limit in order to achieve full employment (Muhammad 1980, 105). 
The socialist economists view fiscal policy as rules intended for public investment interests. This policy contains interest to consider public expenditure and income to adjust the level of economic activities as a whole and to reduce volatility (Muhammad 1980, 105).

Generally, fiscal policy is an economic policy that directs a nation's economy to prosperity by reforming government income and expenditure systems. This policy is akin to the monetary policy that regulates money circulation ("UU No. 23 Tentang Bank Indonesia” 1999; Yuswar Zainul Basri and Mulyadi Subri 2003, 23). However, the fiscal policy emphasizes on the management of government income and expenditure.

Some argue that fiscal policy is related to taxation. The fiscal policy is determined by the department of finance, which its duties are to study, analyze, implement and evaluate the policy implementation to reach optimal goals, along with the measures taken to resolve a problem related to the taxation (Irham Fahmi 2013, 223).

Samuelson maintains that fiscal policy is a process of setting taxes and government expenditure in order to help minimize fluctuations in the economic cycle and maintain economic growth, high employment opportunities and prevent the economy from high and volatile inflation (Paul A. Samuelson and William D. Nordhaus 2009, 354).

Muhammad interprets fiscal as one part of political instruments; and the fiscal policy is a policy related to provisions, maintenance and payment of the resources needed to fulfill and maintain public needs (Muhammad 2002, 179). Parkin defines fiscal policy as the use of the state budget to achieve macroeconomic goals, such as the level of full employment, long-term economic growth and price stability (Michael Parkin 2012, 224). Mulyadi Subri states that fiscal policy is the policy carried out by the government related to government revenue and expenditure (income and spending) (Yuswar Zainul Basri and Mulyadi Subri 2003, 23). Jhingan states fiscal policy as the use of tax, public loan, and public expenditure by the government to create economic stability and growth (M.L. Jhingan 2000, 374).

Frans Seda explains fiscal policy as economic science that encompasses every policy related to the state budget (Frans Seda 2004, 76). Furthermore, he claims that fiscal policies with high and continuous deficit can affect monetary policies (Frans Seda 2004, 78).

Fiscal policy in a country is an important element related to the existence of a state budget that directly affects the aggregate demand (Rudiger Dornbusch and Stanley Fischer 1994, 141). The main elements in fiscal policy are inseparable from expenditure and revenue. 
The state budget can be categorized into three types - first, budget deficits or expansionary fiscal policies (W. Riawan Tjandra 2013,2). The budget deficit is a government policy to make expenditure more than the income obtained by the state to provide stimulus to the economy. This policy will be very well used in recessive moderate economic conditions (Franco Modigliani and Arlie Sterling I986, 76). The next is the budget surplus (surplus budget) or contractive fiscal policy, which is a government policy to make the income more than the expenditure. The surplus budget is implemented when the economy is in an expansionary condition that is starting to heat up (overheating) to reduce demand pressure. The last is a balanced budget, which occurs when the government determines that expenditure must equal income (John Lindauer 1971, 175).

The political aim of a balanced budget is to create certainty of budget and improve the discipline in budget usage (John Lindauer 1971, 171). Balanced Budget Fiscal Expansion is an attempt to increase aggregate demand by changing the spending and taxation levels while leaving the overall fiscal budget situation the same. The increased government spending has a bigger positive impact on economic growth than the negative impact of higher taxes. The surplus or deficit of a government budget is in part affected by the level of income and full employment usage. The surplus in the budget is caused by high state income and vice versa. Low state income will, in turn, cause a budget deficit.

Budget deficit policy, which is commonly applied in developing countries, will affect the economy. The effects of budget deficit towards the economy are viewed through three different standpoints, Ricardian, Neoclassical and Keynesian (R. Maryatno 2012, 141). Ricardians with their theory of Ricardian Equivalence Hypothesis (REH) argue that the economy is not affected by the budget deficit. This theory is stemmed from David Ricardo's Funding System and repopularized by Robbert Barro (Robert J. Barro 1976, 345-350). Therefore, this theory is often referred to as the Ricardo-Barro Preposition. The preposition constructed by Ricardo Barro is of intergenerational altruism or immortality, perfect capital markets and lump-sum taxation. This proposition, essentially, states that the payment of government budget deficits and debts neutrally affect economic activity (Blancard 1990). The hypothesis made is that the impact of government policy on the economy is not of importance (neutrality preposition) (Nouriel Roubini 1988, 13).

REH theory combines two fundamental approaches, that is of government budget constraints and Permanent Income Hypothesis (PIH). Government budget constraints state that if government expenditures stay constant, low tax rates will, later on, be offset by the rise in tax rates. Meanwhile, PIH states that household decisions towards consumption are based on permanent income, which, in turn, 
is greatly affected by the amount of income after tax. Based on that analysis, the payment of budget deficit by lowering tax now will affect the tax burden later on but not in present value. This tax deduction will not alter permanent income nor consumption.

Barro brings up the argument that every payment in budget deficit done by issuing bonds will be offset by the rise in tax rates later on (Robert J Barro, n.d.). The increase in tax rates does not need to make people afraid of their prosperity or wealth. This is because the oncoming rise in tax rates will be anticipated by increasing savings and reducing current spending. The implication is that individuals will not use all of their income and wealth for consumption because of the issuance of state bonds. Individuals will save all of their income and wealth to anticipate the rise in tax rates, with the result being the rise in demand towards goods and services.

If the government increases the current tax to pay for state bond debt, an individual will perceive this policy as the same as substituting current tax with upcoming tax (with the same present value). Budget deficit policy set by the government is fundamentally a tax diversion from now to the future. Therefore fundamentally, budget deficit policies do not affect the economy (Robert J. Barro 1976, 350).

$\mathrm{REH}$ argues that the changes in tax and budget deficit payment have the same effect on macro variables (especially private sector consumption). REH construct a premise that the issuing of state bonds will be accompanied by the rise in tax in the future. The payment of government debt is assumed to only change according to changes in taxation, and thus, the aggregate consumption will stay constant. Individuals in the REH framework assume that the upcoming tax to be equal with a load of national debt (Robert J Barro, n.d.). Hence, REH does not recommend the application of budget deficit policies.

The Neoclassics also research the impacts of government budget deficit policies. The Neoclassics believe that each individual possesses enough information in order to plan their level of consumption. The budget deficit will, in the long term, increase the amount of consumption by passing the tax burden to the next generation. If every little bit of resource is usable, the rise in consumption will lower savings and raise interest rates. The rise in interest rates will cause private investment to drop. Neoclassics conclude that in full employment, the permanent budget deficit will cause private investment to be driven out (Crowding-out). Therefore, Neoclassics declare that the budget deficit will negatively impact and hurt the economy (R. Maryatno 2012, 143). This conclusion is akin to the Ricardian Equivalence Hypothesis theory. 
The third view is that of Keynesians who put forward the argument that the budget deficit will, in fact, positively impact the economy. Keynesians assume that economic agents only think for short-term and not long-term (myopic); there is a lack of inter-generation relationship; and not every market is in equilibrium. If the economic agents only think for short-term, then budget deficit policies to increase public income will be responded to by the increase in consumption, which, in turn, boost production rates (R. Maryatno 2012, 144).

Keynesians believe the budget deficit will increase income, welfare and consumption. Debt funded budget deficit means the burden of tax now will relatively lighten and cause a rise in spendable income (Dono Joyo Subroto 2006, 85). The rise in spendable income will increase consumption and demand as a whole. If the economy is in full employment, the rise in demand will increase production, inducing a rise in national income. In the next period, through the Keynesian multiplier effect, a rise in national income will boost the economy. The budget deficit will increase consumption and income all at once; savings and capital accumulation will also increase. Therefore, the short-term budget deficit will benefit the economy (R. Maryatno 2012, 145).

Fiscal policy will affect the national economy through state revenue and expenditure. State revenues are taxes and other levies obtained by the government from the domestic economy, which, in turn, can infer a contraction in the economy (Dono Joyo Subroto 2006, 89). Meanwhile, the state expenditure is the spending done for government operations and projects funding in state sectors or by stateowned enterprises (Dono Joyo Subroto 2006, 90).

The review of contemporary fiscal policy is also closely linked to the idea of the need for cooperation between monetary and fiscal works. This is relevant to set and achieve monetary targets as well as state budget goals consistently in order to achieve high and stable economic growth. On the other hand, this cooperation also promotes growth in the financial market and supports the execution of monetary and fiscal policies through information exchange (R. Maryatno 2012).

The fiscal policy is used to influence the economy by adjusting revenue and spending levels. The two main tools in fiscal policy are taxes and spending. Taxes influence the economy by determining how much money the government has to spend in certain areas and how much money individuals should spend. The state expenditure is everything related to state spending needed to fund state operations for the nation to run and run well (R. Maryatno 2012). This budget in Islamic jurists is known as muwäzanah or mizänīyah (Hana Razuqi 1976, 3). Budget in Islam can be interpreted as the spending of an Islamic nation from their treasury (Bait al-Māl) to fulfil public needs in accordance with Islamic sharia (Husain Ratib Yusuf Rayyan 
1999, 140). Budget can also be defined as a financial work plan, which on one side contains the highest amount of expenditure probably needed to fund state needs in the future. Budget can also mean a plan needed to fund activities, including government operations (W. Riawan Tjandra 2013, 16).

Determining the state budget or expenditure requires clear principles so that the expenditure system is in accordance with the common needs. Adam Smith, as one of the Western economists, stated that the government expenditure system must have several principles, such as (a) The principle of morality, in which the government expenditure must be in accordance with the values upheld by a nation, namely religion. (b) The principle of nationality, which means that government expenditure must pay attention to the interests of the people at large and the nation. (c) The principle of popularism, meaning that government spen ding must pay attention to the interests of the people and uphold the sovereignty of the people. (d) The principle of functionality that government spending $m$ ust be based on a predetermined function. (e) The principle of rationality, which means that the government expenditure must be rational by paying attention to the efficiency and effectiveness of expenditure. (f). The principle of development is that government expenditure must be in accordance with the development of the country and the world. (g) The principle of balance and justice, meaning that there must be a balance between government expenditure between physical activit i es and non-physical activities in order to create harmony and harmony (Adam Smith 1993, 442).

Principles that limit government expenditure based on the ability of a country to earn revenue is: (a) pay as you go principle, which means that the government expenditure is limited by their capability to fund it from routine revenue and development; (b) tax rate limitation, which means that government expenditure must be based on national revenue from taxations; (c) debt rate limitation, which means that the government expenditure is dependent on the amount of revenue earned by the government (Adam Smith 1993, 448).

Based on the objectives to be achieved, the government expenditure must fulfill the following principles: (a) the economizing principle, which means that government spending should be as economical as possible so that the mobilization of funds issued is right on the target; (b) better selection of alternative principles, where every government expenditure should be in the form of a decision result based on the choice of various alternatives proposed; (c) more performance at money expensed, which means that every government expenditure is expected to increase community income, which in turn will grow the country's economy (Adam Smith 1993, 449). 


\section{State Budget Management According to Ibn Khaldun}

Budget management, according to Ibn Khaldun, has to be based on sharia law while also paying attention to the principles of public welfare. Money and other assets accumulated from the people through tax and other levies must be used for the people through public services (Khaldun 1993, 238).

In an ideal country, according to Ibn Khaldun, state budget management has to be allocated primarily for public welfare while also keeping in mind the interests of governments and rulers. The use of state budget has to be able to accommodate two main interests, public and government interests. Both have to be considered but with public welfare as the priority (Khaldun 1993, 238).

The state is responsible for managing the budget to achieve the socio-economic goals of the people. State expenditure must have six goals in mind: first, towards state defence and security. A strong nation needs a strong ruler, and state power is kept with the presence of a strong national defense. State revenue in early Islamic states, which mainly comes from Gharaim Sharia such as zakat, fay', ghanimah and jizyah were primarily used for national defense and war. Certain spoils of war in the form of land, in the case of Fadak and Banu Nazir, were used to fund wars in the age of the Prophet Muhammad (Abu Ubayd 1989, 14). According to Ibn Khaldun, a strong national defense will strengthen nationalism. The spirit of nationalism is key in national development (Khaldun 1993, 138).

Second, budget expenditure with means to meet the basic needs of the people. People's basic needs have to be the main objective in state budget expenditure. Basic needs, which covers food, clothes and shelters, are the main purpose of budgeting. Gharimah Sharia and taxes collected from the people has to be returned to the people by fulfilling the basic needs of the people. Ibn Khaldun emphasizes that the use of the state budget has to prioritize the needs of the people before the interests of the ruler.

The third is the usage of the state budget for public services. Together with the growth of a country, a satisfactory public service administration must be arranged. Civil servants comprising of office employees, judges, teachers, governors and alike that serve public interest must also be a purpose in state budget expenditure. Ibn Khaldun underlines the responsibility of a ruler to meet the public needs of their people, such as hospitals (Khaldun 1993, 140).

Fourth, social security goals, including donations and state budget pension plans, must also be spent on social security purposes. A caliph once ordered a governor to assist non-Muslims who were old, weak and blind and also elderly citizens (Abu Ubayd 1989, 46). This shows that state budgeting in the early days 
of Islam included social security. Umar bin Khațāâb maintained his social security in the form of providing retirees for elderly citizens, war widows and also paying off debts for poor people who cannot afford to pay debts (Abu Ubayd 1989, 50). Umar also gave monthly rations to war veterans. Umar himself once gave monthly rations to war veterans. The source of the budget used by Umar was from ghanimah and fay. More than that, Umar also offered to help with the cost of marriage for the poor (Abu Ubayd 1989, 250). Other concerns were also addressed to converts by providing financial assistance from the state treasury (Abu Ubayd 1989, 265). Ibn Khaldun suggests that state budget spending also aims to provide direct assistance to the poor and starves (Khaldun 1993, 139). This is evidence that the objectives of managing the state budget, according to Islamic scholars, must also be oriented towards social security. Umar once paid teachers to teach the Koran in remote areas. State budget spending must also focus on aspects of education.

Fifth, state budget spending must also address educational goals by providing appropriate educational services for the community. At the beginning of Islam, education was an important goal in the spending of the state budget (Abu Ubayd 1989). The Prophet Muhammad, once, made education and training a ransom for prisoners of war (Abu Ubayd 1989, 267). This shows that education is an important goal in the spending of state budgets. This is because, usually, prisoners of war could only be redeemed by paying a sum of money that would be used as state assets.

Sixth, spending on the state budget is to build public facilities. To strengthen economic development and improve people's welfare, the construction of facilities and infrastructure projects must be the goal of state budget spending. The facilities include roads, bridges, construction and other means of transportations, drainage, as well as other types of the portion of the budget (Abu Yusuf 1979, 267). The expenditures for the public facilities have been funded by the government to boost economic growth. Early Islamic reign is the main focus in government budget spending.

The budget policy is a strategy to influence and process the State Budget (APBN). The government has a responsibility in managing the state budget. Government has a very large responsibility in the context of the state budget. As Ibn Khaldun states that more government spending increases, the greater the activities financed by the government and the more economic activities expanded. Thus, the management of the budget with the proper budget allocation will increase national income for the country. The theory of positive correlation between government activities and government budget also expresses by Wagner. Wagner states that the expenditures from government activities will increase (Harvey S. Rosen and Ted Gayer 2008, 29). 
According to M.A. Manan, conventional economics view budget policy aims towards welfare, as indicated by maximum profit for an individual without factoring human spiritual needs (M.A. Manan 1991, 38). While Islamic economics views budget managing as a means to achieve sharia goals, in the form of economic welfare while also maintaining faith, intellect, wealth and ownership. In this case, faith plays an important role in managing the state budget (Machmud Shaikh Ahmad 1995, 34-35).

According to Ibn. Khaldun, the allocation of state budget spending is adjusted according to national income. The main source of national income is in the form of tax, followed by incomes from religious provisions, zakat, alms, fay', ghanimah and kharraj (Khaldun 1993, 218). As a result, allocation of budget spending is adjusted according to income. Ibn Khaldun explicitly states that national income sourced from maghrim sharia has to be allocated according to sharia laws or the Quran and hadith.

The amount of nominal that should be given to each group of recipients is still debated by the scholars. Abu Ubayd states that there is no certainty of the argument about the amount or nominal that must be given to each group (Abu Ubayd 1989, 562). As for the distribution of territory, Abu Ubayd states that area, where zakat is collected, have more rights for zakat distribution, to eliminate jealousy among the poor (Abu Ubayd 1989, 586).

State income earned from ghanimah property must be spent according to the rules in the Quran. Income from Ghanimah has to be divided into two: 4/5 part is allocated for the army and state security officers. 1/5 part, called khumus, is allocated to the way of God. In this case, it is deposited in the state treasury for other purposes related to mutual benefits (Quran surah al-Anfāl verse 41).

State budget obtained from zakat has to be allocated according to laws in the Quran. Zakat is only to be allocated to eight groups called the mustahiq zakat (Quran surah al-Taubah verse 60). As for the amount given to each group, it is still a debatable issue. The region in which said zakat is collected receives a right to a bigger allocation of zakat funds. This is to eliminate jealousy and spite among the poor.

The allocation of state income sourced from fay' is based on the seventh verse of the Quran chapter of The Exile. Fay' is allocated for Allah, the Prophet Muhammad and his relatives, orphans, the poor as well as travellers. According to Imam al-Ghazali, government incomes sourced from fay' are to be used for the welfare of Muslims, like the building of bridges, mosques, roadways and other public needs. Abu Yusuf recounts the time Umar achieved victory over the Persians and the Romans. He, along with a few other companions, discussed the distribution of fay'. 
As a result, Umar gave the companions that took part in the war 5000 Dirham, while those who did not take part received 4000 Dirham and. Each of the Prophet's wife, on the other hand, received 12.000 Dirham.

Meanwhile, national income sourced from tax, customs and other nonsharia levies were allocated for better public welfare. This becomes the authority of the ruler to manage the budget expenditure based on the principle of public welfare. Ibn Khaldun emphasizes that the distribution of state budget allocation to consider public welfare and not solely for the interest of the rulers and those around him.

\section{Conclusion}

The balanced budget policy is intended to create a balance of budget while also improving the discipline of budget usage. As a result, legislators are required to create a source of income or self-sufficiency for the people and provide power to the government to carry out its duties.

Issues that frequently occur are of inflation and unemployment. Inflation is caused by a society wanting to live outside of their economic capabilities. Unemployment is caused by the level of economic activity reached being lower than with full employment.

Fiscal policy, according to the capitalist economists, is the effort to create investment growth and to eradicate the fluctuations in economic activities as a whole. Another purpose is to bridge the gap between inflation and deflation. Keynes states the rise of demand is heavily dependent on government effort to decrease taxes and increase spending. This results in the increase of people's spendable income and their consumption. Government policy manages demand by channelling demand towards goods and services in surplus

Ibn Khaldun argues that budget management has to pay attention to public issues while also tending to government interests. Budget expenditure has to have six goals, namely the matter of national security and defense; the basic needs of the poor; public services; social security, such as alms and pension plans; educational services; and public facilities. Allocation of state budget expenditure according to Ibn Khaldun is adjusted according to state income. The main source of national income is from taxes and then followed by incomes from religious provisions like zakat, alms, fay', ghanimah and kharraj. 


\section{References}

Abdullah M. Farid. 1985. Dictionary Al-Fareed in Finance and Economic. Kairo: Dār al-Kutub.

Abū Ubayd. 1989. Kitāb Al-Amwal. Beirut: Dār al-Shurūq.

Abu Yūsuf. 1979. Kitāb Al-Kharrāj. Beirut: Dār al-Ma‘āif.

A.C. Pigou. 1951. A Study in Public Finance. London: Macmillan.

Smith, Adam. 1993. An Inquiry into the Nature and Causes of the Wealth of Nations. Oxford: Oxford University.

Sutedi, Adrian. 2012. Hukum Keuangan Negara. Jakarta: Sinar Grafika.

Blancard. 1990. "The Sustainability of Fiscal Policy: New Answers to an Old Question.” OECD Economic Studies 15. http://www.nber.org/papers/r1547.

Deliarnov. 2006. Ekonomi Politik. Jakarta: Penerbit Erlangga.

Subroto, Dono Joyo. 2006. "Koordinasi Kebijakan Fiskal Dan Moneter di Indonesia." in Kebijakan Moneter Dan Fiskal Dalam Islam, ed. Heru Subiyantoro. Jakarta: Salemba Empat.

Faridi. 1983. "Theory of Fiscal Policy in an Islamic State." Journal Res. Islamic Economic 1(1): 15-30.

Modigliani, Franco \& Arlie Sterling. I986. "Government Debt, Government Spending and Private Sector Behavior: Comment." American Economic Review 76(5): 1168-1179.

Seda, Frans. 2004. "Kebijakan Anggaran Penerimaan Dan Belanja (APBN) Berimbang dan Dinamis." In Kebijakan Fiskal: Pemikiran Konsep Dan Implementasi, ed. Heru Subiyantoro \& Singgih Riphat. Jakarta: Kompas.

Pilling, Geoffrey. 1987. The Crisis of Keynesian Economics: A Marxist View, Kent, UK. Croom Helm Ltd. www.marxists.com.

Abbott, George C. 1985. "Reviewed Work(s): What Is Political Economy? A Study of Social Theory and Underdevelopment. by Martin Staniland." Wiley on Behalf of the Royal Institute of International Affairs Stable 62(1). http://www. jstor.org/stable/2618090.

Razūqī, Hanā. 1976. Al-Muhāsabah al-Hukūmīyah. Baghdad: Dār al-Thaqāfah alIslāmīyah.

Rosen, Harvey S., and Ted Gayer. 2008. Public Finance. New York: McGraw-Hill.

Herzon Y. n.d. Politik Anggaran: Studi Tentang Proses Perumusan Kebijakan Anggaran Belanja Langsung SKPD Dalam Penyusunan APBD Tahun 2011 Di Kabupaten Kerinci Provinsi Jambi. Accessed August 3, 2016. http://etd. 
repository.ugm.ac.id/index.php?mod=penelitian_detail\&sub=PenelitianDet ail\&act=view\&typ=html\&buku_id=53660.

Rayyan, Husain Ratib Yūsuf. 1999. 'Ajzu al-Muwāzanah Wa Ilājuhu Fi al-Fiqh alIslāmì. Jordan: Dār al-Nafāis.

Fahmi, Irham. 2013. Ekonomi Politik: Teori Dan Realita. Bandung: Alfabeta.

Viner, Jacob. 1936. Mr Keynes on The Causes of Unemployment. Oxford University Press: The Quarterly Journal of Economics 51(1): 147-67.

Lindauer, John. 1971. Macroeconomic. California: Claremont Graduate School.

Keynes, John Maynard. n.d. The General Theory of Employment, Interest and Money. Retrieved December 25, 2015. from www.isn.etzh.ch.

Khaldūn, Ibn. 1993. Muqaddimah Ibn Khaldūn. Beirut: Dār al-Kutub al'Ilmīyah.

Manan, M.A. 1991. Islamic Economics: Theory and Practice. Pakistan: Shah Muhammad Ashraf Publisher.

Ahmad, Machmud Shaikh. 1995. Economics of Islam: A Comparative Study. Pakistan: Shah Muhammad Ashraf Publisher.

James, Michael. 2001. Pembangunan Ekonomi di Dunia Ketiga. Jakarta: Ghalia.

Parkin, Michael. 2012. Macroeconomic. New York: Pearson Education, Inc.

Jhingan, M.L. 2000. Ekonomi Pembangunan Dan Perencanaan (Terj). Jakarta: PT Raja Grafindo.

Muhammad. 1980. 'Abdal-Mu'ìn 'Afar, al-Siyāsah al-Iqtis\}'̄àīyah Fì al-Islām. Jiddah: al-Mathba'ah al-Arabiyah al-H\}adītsah.

Muhammad. 2002. Kebijakan Fiskal Dan Moneter Dalam Ekonomi Islam. Jakarta: Salemba Empat.

Mankiw, N. Gregory. 2006. Teori Makro Ekonomi, Terj. Nachrowi Dan Usman. Jakarta: PT. Gramedia Pustaka Utama.

Philipus, Ng. \& Nurul Aini. 2004. Sosiologi Dan Politik. Jakarta: PT. Raja Grafindo.

Nopirin. 1998. Ekonomi Moneter. 5th ed. Yogyakarta: BPFE.

Roubini, Nouriel. 1988. "Current Account and Budget Deficits In An Intertemporal Model Of Consumption And Taxation Smoothing A Solution To The 'Feldstein- Horioka Puzzle'?" Working Paper No. 2773 National Bureau of Economic Research 1050 Massachusetts Avenue Cambridge, MA 02138, November.

Samuelson, Paul A. \& William D. Nordhaus. 2009. Macroeconomics. New York: McGraw-Hill. 
Raharja, Prathama \& Mandala Manurung. 2008. Pengantar Ilmu Ekonomi (Mikro Ekonomi Dan Makro Ekonomi). 3rd ed. Jakarta: Lembaga Penerbit Fak. Ekonomi Universitas Indonesia.

Maryatno, R. 2012. "Peranan Asa Nalar Dalam Menentukan Efektivitas Kebijakan Defisit Anggaran," in Koordinasi Dan Interaksi Kebijakan Fiskal-Moneter: Tantangan Ke Depan, ed. Sri Adiningsih. Yogyakarta: Penerbit Kanisius.

Barro, Robbet J. n.d. "Optimal Manajement of Indexed and Nominal Debt." NBER Working Paper No 6197.

Barro, Robert J. 1976. "Perceived Wealth in Bonds and Social Security and the Ricardian Equivalence Theorem: Replay to Feldstein and Buchanan." Journal of Political Economy 84(2): 345-50.

Robert Skidelsky \& Robert Jacob Alexander Skidelsky. 2008. John Maynard Keynes, 1883-1946: Economist, Philosopher, Statesmen. UK: Penguin Books.

Roslinda. 2013. "Kebijakan Fiskal, Pengaruh Dan Efektifitasnya dalam Perekonomian Indonesia." April 15, 2013. www. rosalindasitakar.blogspot. co.id.

Dornbusch, Rudiger \& Stanley Fischer. 1994. Makro Ekonomi. Jakarta: PT Erlangga.

Kale, Sumita. 2008. "A Global Keynesian Revival,” February. www.livemint.com.

Todaro. 2002. Ekonomi Dalam Pandangan Modern, Terj. Jakarta: Bina Aksara.

Smith, Tony. 1985. Reviewed Work(s): What Is Political Economy? A Study of Social Theory and Underdevelopment by Martin Staniland. College of Business, Tennessee State University Stable 20(1): 122-24.

Law No. 23/1999 Tentang Bank Indonesia.

Tjandra, W. Riawan. 2013. Hukum Keuangan Negara. Jakarta: Grasindo.

Basri, Yuswar Zainul \& Mulyadi Subri. 2003. Keuangan Negara Dan Analisis Kebijakan Utang Luar Negeri. Jakarta: PT Raja Grafindo. 